\title{
First records of Trichoptera from Timor-Leste, including seven newly described species
}

\author{
ALICE WELLS $^{1 *} \&$ DAVID CARTWRIGHT ${ }^{2}$ \\ ${ }^{1}$ Australian National Insect Collection CSIRO, PO Box 1700, Canberra, ACT 2601, Australia \\ "=alice.wells@csiro.au; @ ittps://orcid.org/0000-0001-5581-6056 \\ ${ }^{2} 13$ Brolga Crescent, Wandana Heights, Victoria 3216, Australia \\ "=davidcartwright3@bigpond.com; @ https://orcid.org/0000-0002-3050-1469 \\ "Corresponding author. "= alice.wells@csiro.au
}

\begin{abstract}
Several collections of adults of the caddisfly order Trichoptera were studied from Timor-Leste, the nation-state comprising the eastern region of the island of Timor. The specimens represent ten families: Hydrobiosidae ( 2 species), Glossosomatidae (1 species), Hydroptilidae (3 species), Philopotamidae (5 species), Hydropsychidae (3 species), Polycentropodidae (1 species), Psychomyiidae (3 species), Xiphocentronidae (1 species), Lepidostomatidae (1 species), Leptoceridae (3 species). Among the 24 species listed, 16 were identified as established Southeast Asian species. Among these are two very widespread species, one extending further east to New Guinea, northern Australia, and New Caledonia and another that was described from Fiji. An additional seven species are newly described here: Ulmerochorema hatubuilico sp. nov., Hydroptila bellisi sp. nov. and $H$. aileuensis sp. nov., Chimarra lawaliu sp. nov., C. multidentata sp. nov., C. sameana sp. nov. and C. timorensis sp. nov. Hitherto, the genus Ulmerochorema Mosely was believed to be an Australian endemic. A xiphocentronid specimen could be identified to genus Drepanocentron only.
\end{abstract}

Key words: microcaddisflies, new species, checklist, vesica

\section{Introduction}

Records of aquatic insects from the island of Timor are few (see Polhemus \& Polhemus 1994). This report is the first record of Trichoptera, based on some collections from Timor-Leste, the nation-state comprising the eastern portion of the island (Fig. 30). Geographically, Timor is situated well towards the eastern end of the Indonesian Archipelago (about $8.87^{\circ} \mathrm{S}, 125.73^{\circ} \mathrm{E}$ ) and experiences seasonal monsoons. The island is mountainous, being derived from ' $\ldots$ geological processes associated with the Timor tectonic collision' (Audley-Charles 2011). The terrain, together with the heavy rains of the monsoons and the instability of landscapes, has resulted in runoff with heavy sediment loads and the consequent development of large, braided rivers fed by networks of small, mostly intermittent, streams. Such systems tend to support a rather limited set of aquatic invertebrates (Polhemus \& Polhemus 1994), often species that are widespread, some probably exhibiting tolerance of somewhat adverse conditions such as moderate levels of pollutants, low oxygen levels, and higher temperatures. Nonetheless, the rather limited samples available represent a reasonably extensive range of families, albeit only few genera and species within those families.

A total of 24 species from ten families are listed: Hydrobiosidae (2 species); Glossosomatidae (1 species), Hydroptilidae (3 species); Philopotamidae (5 species); Hydropsychidae (3 species); Polycentropodidae (1 species); Psychomyiidae (3 species); Xiphocentronidae (1 species); Lepidostomatidae (1 species) and Leptoceridae (4 species). The larvae of these families include most trophic groups: predators, scrapers, scavengers, and filter-feeders.

All but one of the Timor-Leste genera and even many of the species are recorded from elsewhere in the Indonesian Archipelago and Southeast Asia. One species that is widespread in Southeast Asia was described from Fiji, and seven are newly described here. The surprising genus is the hydrobiosid Ulmerochorema Mosely 1953 (in Mosely \& Kimmins 1953), with U. hatubuilico sp. nov. the first member of the genus to be recorded from beyond eastern Australia (note, some $2360 \mathrm{~km}$ from the nearest species in northeastern Queensland!). 
The close connection of Timorese Trichoptera with the broader Southeast Asian fauna is apparent from the list of Malicky et al. (2014) of the Trichoptera of three of the Indonesian islands to the west of Timor, although TimorLeste lacks several of the genera. It is consistent, too, with the findings of Polhemus and Polhemus (1994) for a limited number of aquatic Heteroptera, by Seehausen (2017) for Odonata, and by Köhler et al. (2019) for one genus of terrestrial snails in the camaenid genus Landouria Godwin-Austen. However, it differs from Köhler \& Kessner's (2014) findings for another camaenid: '...Parachloritis appears to be more closely related to northwestern Australian than the Southeast Asian camaenid lineages amongst the outgroup taxa'. Baehr \& Reid (2017), studying another terrestrial group, the carabid beetles from Timor-Leste, found that while 'about two thirds of the ... species belong to, or at least have their roots in, the Oriental Faunal Region, ... about one third ... belong to the Australopapuan Region, either the Papuan or Australian Subregions'.

\section{Material and methods}

Specimens studied are from two collections: the Australian Museum, Sydney (AM), taken on the Australian Museum Expedition during 2011 and 2012, and the Australian National Insect Collection, Canberra (ANIC), collected during survey work in the years 2016 to 2018 funded by the Northern Australia Quarantine Strategy (NAQS) for other insect species. Collection methods varied: Some specimens were taken as 'by-catch' in suction traps set to check for biting midges - Culicoides traps - and others were collected either at UV lights (in bucket traps) or by use of a sweep net. All specimens were collected into $80 \%$ ethanol.

When necessary, specimens were prepared for study by maceration of genitalia in alcoholic potassium hydroxide followed by dehydration and storage in glycerol; specimens of the new hydroptilid species were mounted on slides using Canada balsam. Malicky's (2010) Atlas of Trichoptera of SE Asia was useful for leads to identification of species.

Terminology used in descriptions of Hydroptilidae follows Marshall (1979); for Chimarra follows Cartwright (2002, with the exception of the term 'cornuti' for spines in the phallus); and for Ulmerochorema follows Neboiss (1977).

For established Timor-Leste Trichoptera species in the ANIC and AM collections, brief notes and collecting data are provided; for some, images of male genitalia are included. A list is given of names of species now known to occur in the Timor-Leste fauna.

\section{Taxonomy}

\section{Hydrobiosidae}

Two hydrobiosid genera are among the Australian Museum samples, Apsilochorema and Ulmerochorema. Few hydrobiosids are reported for SE Asia; Malicky (2010) illustrated only 16, all assigned to the genus Apsilochorema. In contrast, the closely related rhyacophilids are diverse. No rhyacophilids are recorded from New Guinea or Australia.

Hydrobiosid larvae are free-living, building cases only as prepupae, and are considered to be predatory (Wiggins 2004).

\section{Apsilochorema moselyellum Kimmins 1955}

Material examined. 1 male, Timor-Leste, above village, Hatu Builico, 8.901942S, 125.516203E, 29-30 May 2012, 1971 m, open grazed Eucalyptus urophylla woodland on rise, Timor-Leste exped. TL2012/093/761 [blacklight bucket trap] (AM K. 395577).

Remarks. This species was described from Sarawak, East Malaysia, and has not been reported from elsewhere in Southeast Asia. 


\section{Ulmerochorema hatubuilico sp. nov.}

(Figs 1-3)

Material examined. Holotype: male, Timor-Leste, above village, Hatu Builico, 8.901942S, 125.516203E, 29-30 May 2012, 1971 m, open grazed Eucalyptus urophylla woodland on rise, Timor-Leste exped. TL2012/093/761 [blacklight bucket trap] (AM K. 395578).

Diagnosis. The male of this new species is distinguished from the eastern Australian Ulmerochorema stigmum (Ulmer 1916) by the shorter, stouter, distally bifid spine midventrally on the apex of abdominal segment IX, and the narrower superior appendages, curved dorsad.

Description. Male. Forewing $8.1 \mathrm{~mm}(\mathrm{n}=1)$.

Genitalia. Sternum IX bearing stout bifurcate process mid-apically, about $1 / 3$ length of inferior appendages. Segment $\mathrm{X}$ elongate, more or less rectangular in lateral and dorsal-ventral views, bearing setae laterally on distal half. Inferior appendages broad, apically bilobed, ventral lobe tipped by short stout peg-like setae. Phallus bearing brush of numerous spinules apically (Figs 1-3).

Etymology. Named for the village near the collecting locality.

Remarks. The genus Ulmerochorema is represented by nine species in eastern Australia, and, until now, appeared to be an Australian endemic. The species from Timor-Leste is most similar to U. stigmum (Ulmer 1916).

\section{GLOSSOSOMATIDAE}

The genus Agapetus Curtis is moderately diverse in SE Asia, as indicated by the 32 species illustrated by Malicky (2010).

Larvae of Agapetus species are generally found on the surface of rocks in cool, fast-flowing streams, but reports concerning some particular species describe them living in small to large streams with low to fast flow and even living in systems with frequent spates such as occur in the seasonal monsoon rivers of Timor-Leste. They build 'tortoise-shell'-shaped cases of coarse sand that they carry around as they feed by scraping epilithos from rock surfaces (Wiggins 2004). Often, abundant cases can be seen on stones, boulders, and bedrock.

\section{Agapetus abbreviatus Ulmer 1913}

Material examined. Timor-Leste: 7 males, 12 females, Aileu Seloi Malere, Aileu River, UV light, 23.viii.2018, A. Wells \& G. Bellis (ANIC).

Remarks. Agapetus abbreviatus, described from West Java, was illustrated by Malicky (2010); it is also known from Bali, Lombok, and Sumatra (Morse 2021).

\section{HYDROPTILIDAE}

Only two hydroptilid genera are represented in the samples available: Hydroptila Dalman and Oxyethira Eaton. Species in the genus Hydroptila are diverse in SE Asia, but few species of Oxyethira have been reported-Malicky (2010) illustrated 69 species of Hydroptila and only seven of Oxyethira; three of the latter are widespread. Two new species are described here in Hydroptila and a new record is given for the widespread O. incana Ulmer 1906. [Unfortunately, non-specialist collectors often discard as micro-moths the very smallest of Trichoptera, the hydroptilids, and none were present in the material from the Australian Museum Expedition.]

Feeding varies considerably among hydroptilid larvae but those of the two genera reported here, Hydroptila and Oxyethira, probably feed on periphyton as early larvae and on filamentous green algae as final instar larvae. 
Hydroptila bellisi sp. nov.

(Figs 4, 5, 11)

Material examined. Holotype: male (on slide), Timor-Leste, Viqueque, Wailakurini via Ossu. 8.799S, 126.3796E, LT, in rainforest near river, 10-12 Sept 2016, G. Bellis (ANIC).

Diagnosis. This atypical species of Hydroptila is assigned to the genus on the basis of absence of ocelli, presence of extensible scent organs under the occipital caps on the dorsum of the head (Fig. 11) and spurs 0,2,4, but in other respects is distinguished from all other species of Hydroptila in the Oriental/Australian Regions by the elaborate form of the male genitalia, particularly the short broad inferior appendages as illustrated and described here (Figs 4, 5), and the elongate slender lateral processes (?parameres).

Description. Male. Head with extensible scent glands beneath occipital lobes (Fig. 11, antennae damaged, bearing close-packed sensilla placodea. Length of each forewing $2.4 \mathrm{~mm}(\mathrm{n}=1)$.

Genitalia: Abdominal segment IX in ventral view shallowly concave apically, pair of narrow processes may represent more usual membranous lateral lobes seen in many Hydroptila species, dorsal-most lobe reaching slightly beyond dorsal plate, shorter one ventrolateral; dorsal plate (segment X) slender, narrow, divided subapically to form pair of small apically acute lobes; inferior appendages in ventral view wide basally, each with slender elongate submesal process bearing strong seta at base, in lateral view deeply crescent shaped; ventral plate short, more or less conical, acuminate apically; phallus with slender titillator between short stout basal part and slender straight distal part, apically slightly flared (Figs 4, 5).

Distribution. Known only from the type locality in southeastern Timor-Leste.

Etymology. Named for Glenn Bellis who collected many of the specimens in this study.

Remarks. This is one of the curious set of species, most from Borneo (for examples see Wells \& Huisman 1992, figs 47, 49; Malicky 2010, p. 34), that are assigned to Hydroptila for want of a more appropriate genus. The general body features conform with those of the genus, but the male genitalic structures are difficult to interpret and may warrant establishment of a new genus.

\section{Hydroptila aileuensis sp. nov.}

(Figs 6-10)

Material examined. Holotype: male (on slide), Timor-Leste, Aileu Seloi Malere, Aileu River, UV light, 23.viii.2018, A. Wells \& G. Bellis (ANIC).

Paratypes: 1 male, 6 females, Viqueque, Wailakurini via Ossu, 8.799S, 126.3796E, LT, in rainforest near river, 10-12 Sept. 2016, G. Bellis (ANIC); 1 male, Emera, Gleno, 8.7150S, 125.4321E, 2 Mar. 2017, Lt G. Bellis (ANIC); 11 males (3 on slides), 3 females, Aileu Seloi Malere, Aileu River, UV light, 22.viii.2018, A. Wells \& G. Bellis (ANIC); 5 males (4 on slides), 16 females (6 on slides), data as for holotype (ANIC).

Other material examined. Numerous males, females, Timor-Leste, Aileu Seloi Malere, Aileu River, UV light, 23.viii.2018, A. Wells \& G. Bellis (ANIC).

Diagnosis. Closely similar to Hydroptila segitiga Wells \& Huisman 1992 from West Malaysia in form of male genitalia, having a single subapical spur, but differing from that species in having the dorsal plate completely divided and the phallus straight, not sinuous apically.

Description. Male. Head with small scent glands beneath occipital lobes (Fig. 9), antennae with 29 flagellomeres, flagellomeres quadrate in profile, bearing close-packed sensilla placodea and each with one sensillum coeloconica. Length of each forewing $2.2-2.5 \mathrm{~mm}(\mathrm{n}=10)$.

Genitalia: Abdominal segment IX retracted into VIII, with pair of slim, pale, apicolateral lobes; dorsal plate (segment X) divided throughout length, forming pair of slender lobes; inferior appendages in ventral view clubshaped, in lateral view rod-shaped, each bearing sharp subapical spur; ventral plate tapered, acuminate apically; phallus with slender titillator between short stout basal part and slender straight distal part (Figs 7, 8, 10).

Female. Length of each forewing $9.5 \mathrm{~mm}(\mathrm{n}=10)$. Antennae comprising 24 flagellomeres. Terminalia (Fig. 6): Abdominal segment VIII elongate, venter broadly rounded apically, with heart-shaped gland medially, its surface rugose; dorsum deeply and widely excavated. Segment IX retracted in segment VIII. Abdominal segment X in dorsal view in form of two slender lobes. 
Distribution. Known only from Timor-Leste, but probably widespread on Timor Island.

Etymology. Named for the river beside which numerous specimens were taken (Fig. 12).
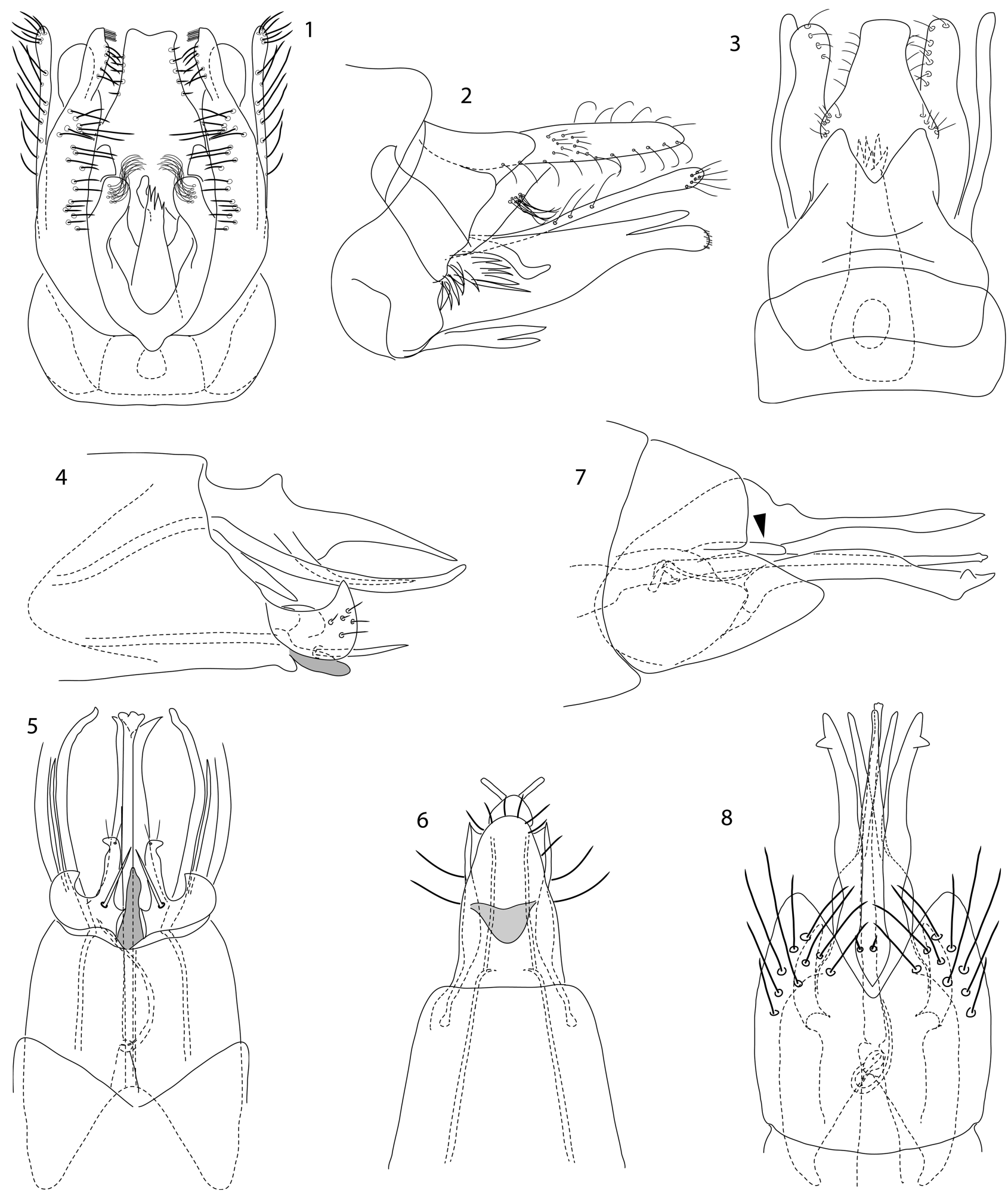

FIGURES 1-8. genitalia. 1-3, Ulmerochorema hatubuilico sp. nov., male: 1, ventral; 2, left lateral; 3, dorsal. 4, 5, Hydroptila bellisi sp. nov., male: 4, left lateral; 5, ventral. 6-8, Hydroptila aileuensis sp. nov.: 6, female, ventral; 7, male, left lateral; 8, male, ventral. 

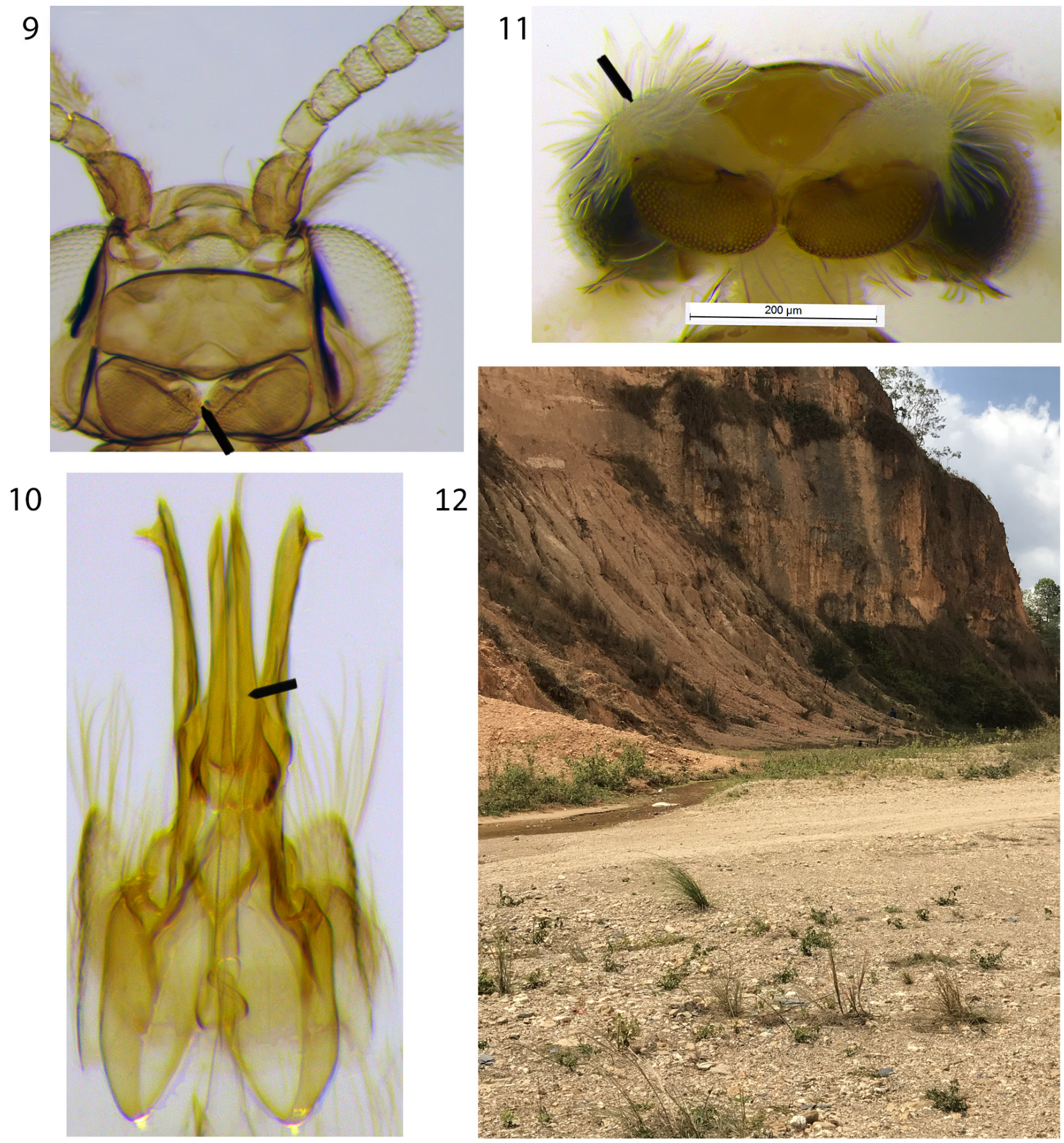

12

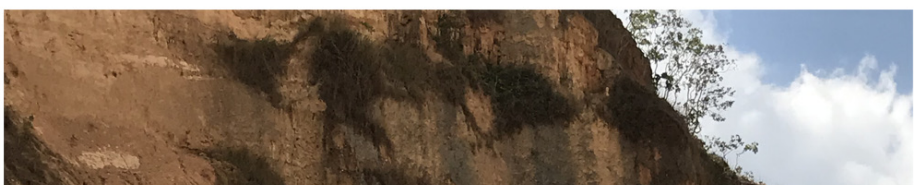

2
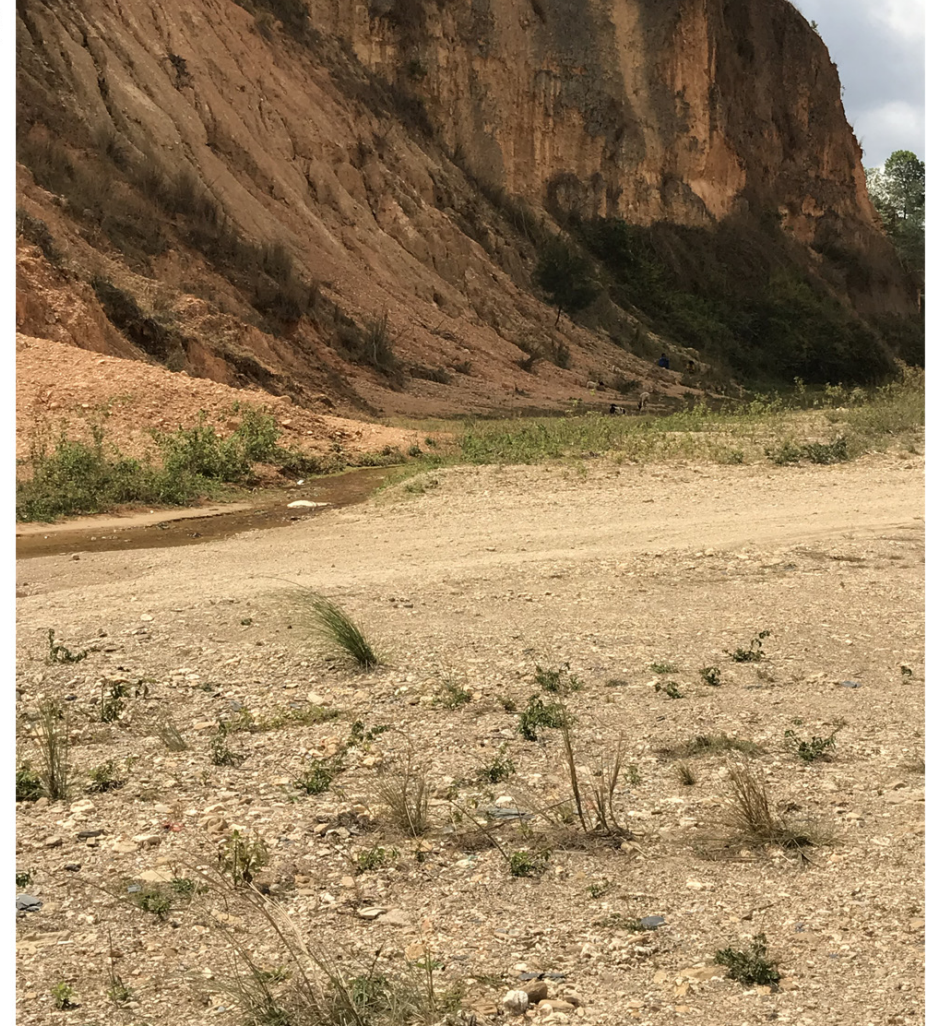

FIGURES 9-12. Hydroptila spp., heads, male genitalia, habitat. 9, Hydroptila aileuensis sp. nov., male: 9, head, dorsal; 10, genitalia, dorsal. 11, Hydroptila bellisi sp. nov., male, dorsal head showing everted scent glands (arrow). 12, Collecting site on Aileu River at Seloi Malere: note broad riverbed and narrow, mid dry season channel, habitat for Agapetus abbreviatus Ulmer 1913, Hydroptila aileuensis sp. nov., Cheumatopsyche lucida Ulmer 1907, Potamyia flavata (Banks 1934), Paduniella koehleri Malicky 1995, Triplectides pallidus (Banks 1936), and Setodes klakahanus Ulmer 1951.

\section{Oxyethira incana Ulmer 1906}

Material examined. Timor-Leste: 11 females, Gleno, at hotel, Culicoides trap, 8.7150S, 125.4321E, 2 Mar. 2017, Lt G. Bellis (ANIC); 2 males, 4 females, Gleno, at hotel, Culicoides trap, 8.7150S, 125.4321E, 27-28 Aug. 2018, G. Bellis (ANIC).

Remarks. Oxyethira incana is one of the most widespread of hydroptilid species, being found throughout the 
Oriental Region, and through the Australian Region from New Guinea and northern Australia to New Caledonia (Morse 2021).

\section{PHILOPOTAMIDAE}

Of six genera in this family recorded from SE Asia by Malicky (2010), only Chimarra is recognised among available collections from Timor-Leste; some 106 species are known from neighbouring Indonesia (Cartwright 2020). Perhaps due to the method of collection, possibly due to the concentration of ethanol into which the specimens of Chimarra were collected, several of them have the vesica of the aedeagus inflated, exhibiting large numbers of fine spicules as illustrated by Cartwright (2001, figs 7-9) and Cartwright (2020, figs 155, 156). In one species described here these spicules appear as a terminal tuft while in two others the spicules are of graded sizes. Matthews (1998) illustrated similar, but very differently shaped, inflation of the vesica of heliothine moths, for which he developed an apparatus for inflating the genitalic preparations in order to be able to demonstrate the variations in form (see Matthews 1998).

Larval philopotamids live in running waters, usually on the under sides of rocks in small streams. They are netspinners that feed on the fine particulate matter that they filter from suspension (Wiggins 2004).

\section{Chimarra batukaua Malicky 1995}

(Fig. 13)

Material examined. Timor-Leste: 1 male, Ainaro District, Guest House, Maubisse, 8.83372S, 125.59636E, 23 May 2012, 1470 m, C. Reid, coffee plantation, TL2012/077/506 [sweep] (AM- K.394723); 1 male, mid-slope Mount Ramelau, 8.9125S, 125.4884E, 28 May 2012, 2520 m, open grazed Eucalyptus urophylla woodland, J. Recsei, D. Britton, C. Reid \& F. Koehler, TL2012/091/576 [hand] (AM- K.394720); 16 males, numerous females, Viqueque, Wailakunni, via Ossu, 10-12 Sep 2016, G. Bellis (D. Cartwright, pers. coll.).

Remarks. The form of a forewing of C. batukaua (Fig. 13) resembles that of $C$. timorensis sp. nov. and $C$. sameana sp. nov. The species was described from Bali (Malicky 1995) and has been recorded also from Java and Lombok (Malicky et al. 2014).

\section{Chimarra timorensis sp. nov.}

(Figs 14, 18-20)

Material examined. Holotype: male, Timor-Leste, Loi-Huno, 8.77836S, 126.37978E; 29 May 2012, 280 m, TimorLeste Exp., TL2012/008/044 [Black light/Bucket trap] (AM-K.395562).

Diagnosis. The wing venation of this species and also C. sameana sp. nov. resembles that illustrated originally for C. ukarumpana Cartwright 2020 from the East Highlands Province of Papua New Guinea but the male genitalia differ from both species. Chimarra timorensis is distinctive in having the curious pair of 'skittle-shaped' structures at the bases of the inferior appendages.

Description. Male. Body and wings uniform brown (in spirits). Wings (Fig. 14) similar to those of C. ukarumpana but with forks 1, 2, and 3 slightly shorter relative to length of discoidal cell. Length of each forewing $4.75 \mathrm{~mm}$ $(\mathrm{n}=1)$. Forewing with forks $1,2,3$, and 5 present, Rs slightly sinuous basal of discoidal cell, fork 1 about $1.5 \mathrm{X}$ length of discoidal cell; hind wings each with distal margin rounded, forks 1, 2, 3, and 5 present.

Genitalia. Segment IX in lateral view short, subquadrate in ventral view and with dorsal margin truncate in lateral view; ventral process (weakly) keel-like; preanal appendages short, rounded apically. Segment X membranous, subquadrate, slightly concave apically; lateral lobes triangular, broadly based. Phallus in distal part spinulose, spinules transparent; internally two irregular-shaped sclerotised structures subapically, pair of slender cornuti (spines) more or less medially. Inferior appendages in ventral view appearing clasper-like, curving posteromesad and tapering to sharp apices; in lateral view stout, curving dorsad, appearing tapered posteriorly (Figs 18, 19); pair of broadbased structures above inferior appendages 'skittle-shaped' and tapering strongly to rounded apices, in lateral view each appearing as slender rod with apical knob (Figs 18, 19, arrows). 
Female unknown.

Etymology. Named for the island of Timor.
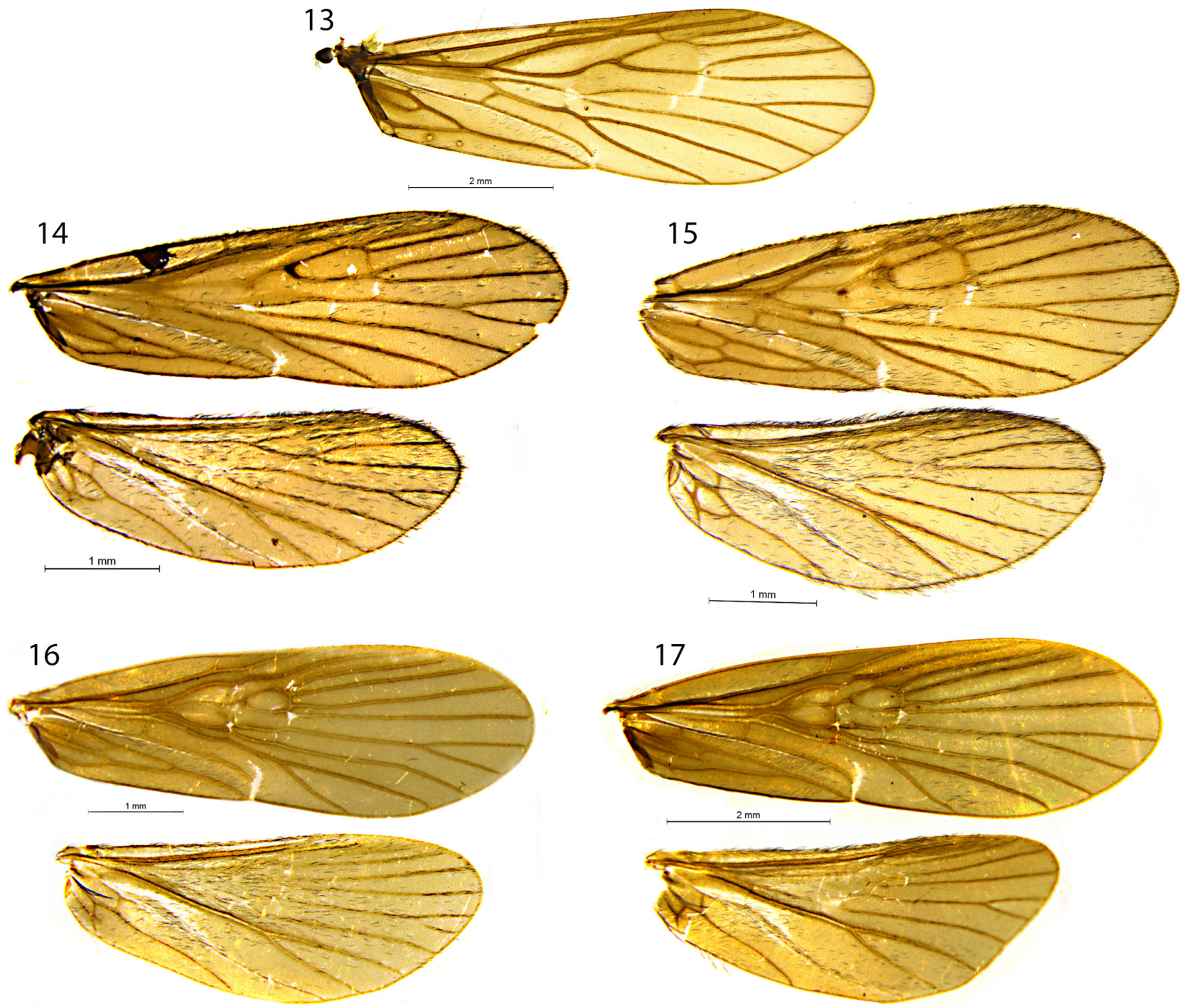

FIGURES 13-17. Right wings of species of Chimarra, dorsal: 13, forewing of C. batukaua Malicky 1995; 14, fore- and hind wings of $C$. timorensis sp. nov.; 15, fore and hind wings of $C$. sameana sp. nov.; 16, fore- and hind wings of $C$. lawaliu sp. nov.; 17 , fore- and hind wings of C. multidentata sp. nov.

\section{Chimarra sameana sp. nov.}

(Figs 15, 21-23)

Material examined. Holotype: male, Timor-Leste, Kablaki Hotel, Same, 8.999969S, 125.648072E, 690 m, 25 May 2012, Timor-Leste exped. TL2012/082/540 [Black light] (AM-K.395582).

Diagnosis. In having segment IX deeply rounded antero-ventrally, this species resembles C. batukaua from Bali and a number of other SE Asian species but the form of the inferior appendages with small, sclerotised, triangular, apicoventral lobes and the strongly upturned lateral lobes of segment $\mathrm{X}$ are distinctive as are the spine-like rods forming the central portion of segment X. In this last feature, although having only one pair of spines, c.f. two pairs, C. sameana shows some resemblance to two northern Australian species: C. akruna Cartwright 2002 from the far north of the Northern Territory and C. pita Cartwright 2002 from the northwestern part of Western Australia; $C$. pita and C. sameana also have similar-shaped lateral lobes on segment X. 

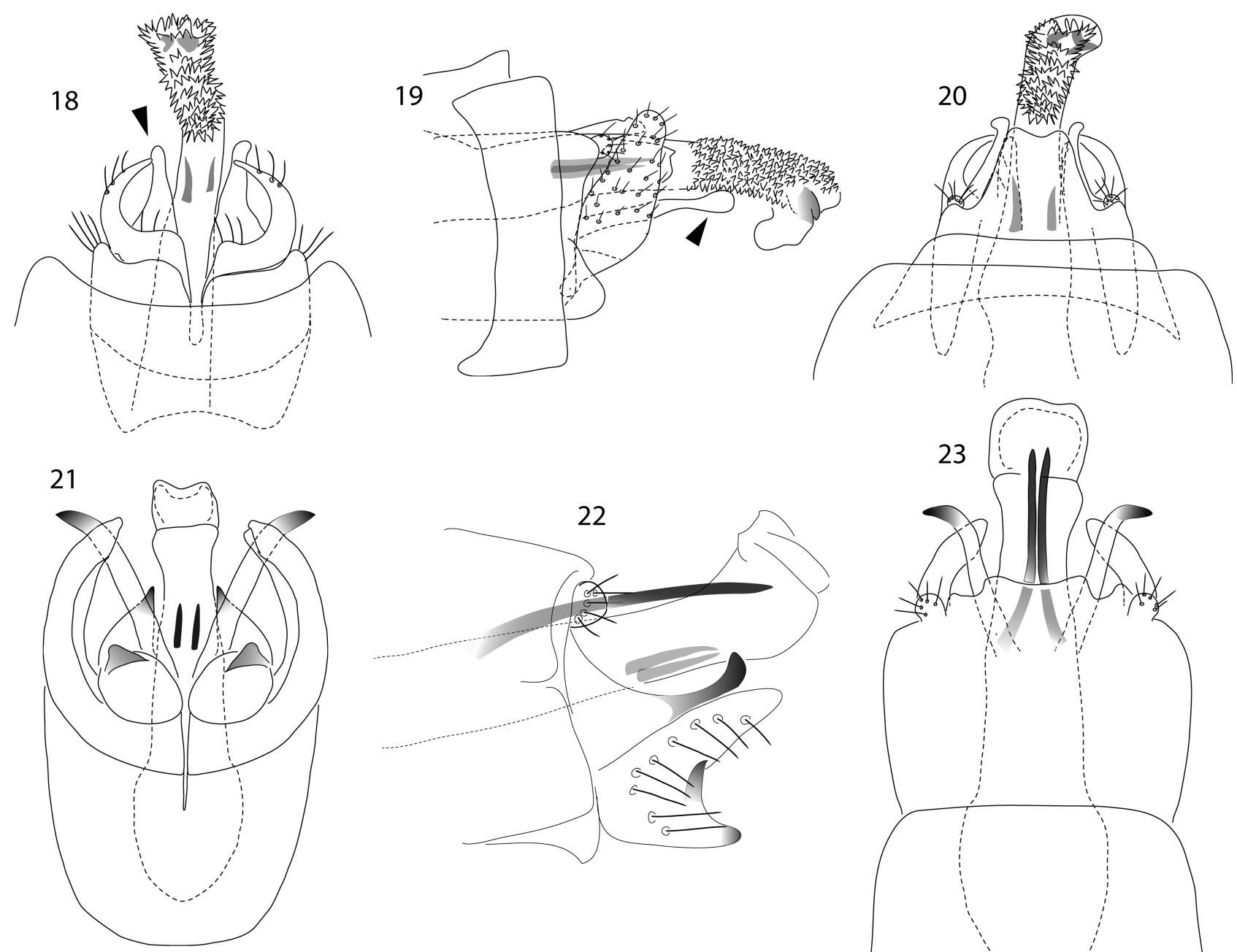

24
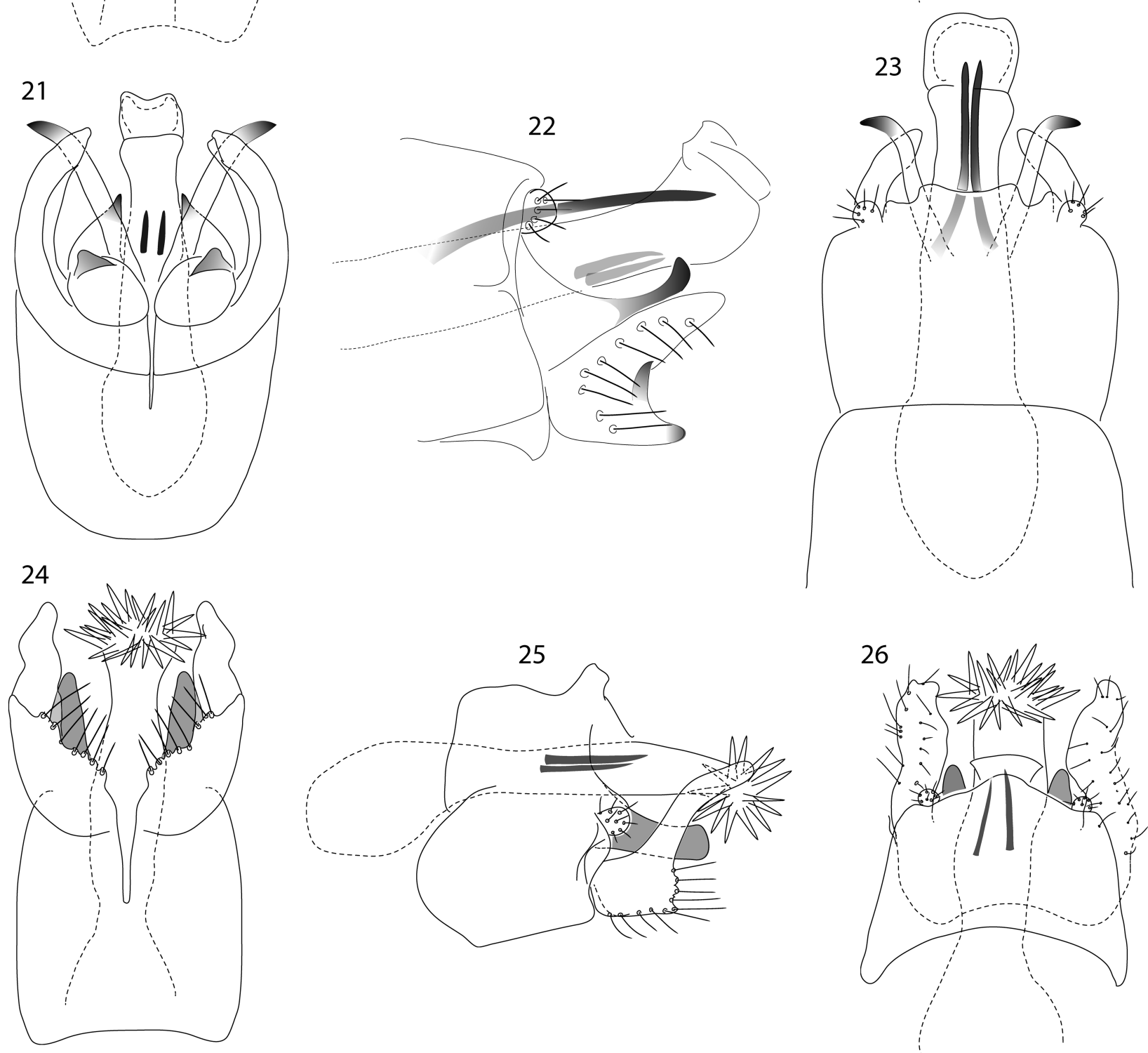

FIGURES 18-26. Chimarra species, male genitalia. 18-20, C. timorensis sp. nov.; 21-23, C. sameana sp. nov.; 24-26, C. lawaliu sp. nov.; 18, 21, 24, ventral;19, 22, 25, left lateral; 20, 23, 26, dorsal.

Description. Male. Body and wings uniform brown (in spirits). Wings similar to C. timorensis, but both broader overall and with broadly rounded apices; each forewing (Fig. 15) length $5 \mathrm{~mm}(\mathrm{n}=1)$. Each forewing and hind wing with forks 1, 2, 3, and 5 present, forewing with Rs sinuous and thickened basal of discoidal cell.

Genitalia. Abdominal segment IX in ventral view strongly rounded proximally, in dorsal view subquadrate with dorsal margin slightly produced apicomedially and almost truncate; ventral process keel-like; preanal appendages 
short, berry-like. Segment X median portion in form of pair of slender sclerotised spine-like rods, lateral lobes slender, curved outwards apically in dorsal-ventral views, in lateral view curved dorsad. Phallus stout, slightly swollen apically, with pair of internal sclerotised cornuti (spines). Inferior appendages in ventral view each with clasper-like lateral arm and rounded basomesal lobe with midventral sclerotised apical prominence that appears as upturned spur in lateral view; in lateral view appearing bifid, with short ventral lobe and longer arching dorsal lobe (Figs 21-23).

Etymology. Named for the collecting locality, Same (pronounced Sah-may).

Remarks. The form of segment $\mathrm{X}$ is distinctive and suggestive of a relationship with the Chimarra kaiya Group species of northern Australia.

\section{Chimarra lawaliu sp. nov.}

(Figs 16, 24-26)

Material examined. Holotype: male, Timor-Leste, Quelicai, telecom tower (Mt Lawaliu), 8.58989S, 126.55236E, 03 June 2012, 695 m, Timor-Leste Exped., 2012/017/058 [MV lamp] (AM- K.395569).

Paratype: 1 male, Timor-Leste, Loi-Huno, 8.77836S, 126.37978E; 29 May 2012, 280 m, Timor-Leste Exp., TL2012/008/044 [Black light/Bucket trap] (AM-K.395561).

Diagnosis. The male of C. lawaliu, together with C. multidentata and some New Guinea species (Cartwright 2020), has forewings each with a depressed area or window proximal to the discoidal cell. The genitalia superficially resemble those of $C$. multidentata but have very prominent paired darkly sclerotised conical lateral lobes on segment $\mathrm{X}$, and in lateral view has the dorsal arm of each inferior appendage more slender and elongate, far exceeding the length of the ventral section.

Description. Male. Head and thorax yellowish, wings and rest of body brown. Length of each forewing: 5.4 $\mathrm{mm}(\mathrm{n}=2)$. Forewings and hind wings each with forks $1,2,3$, and 5 present, forewing with small, clear window proximal to discoidal cell and Rs slightly sinuous basal of discoidal cell.

Genitalia. Segment IX in ventral view almost quadrate, in dorsal view slightly produced in middle distally, with two long, thick setae on each side; anal appendages small, rounded, berry-like. Segment X short, axe-bladeshaped in dorsal view, lateral lobes triangular in ventral view, subrectangular in lateral view. Phallus with brush of sharp transparent spinules at apex. Inferior appendages in lateral view, broadly subquadrate basally, dorsally each with long, curved arm more than $2 \mathrm{X}$ length of basal section; in ventral view basal section stout with distal margin obliquely angled, dorsal arm, robust, sinuous (Figs 24-26).

Female unknown.

Etymology. Named for Mt Lawaliu where the holotype was taken.

\section{Chimarra multidentata sp. nov.}

(Figs 17, 27-29, 31)

Material examined. Holotype: male, Timor-Leste, Mt Laritame, Water Tank 5, 8.69178S, 126.38719E; 31 May 2012; 1150 m, edge of moss forest, TL2012/011/016 [Black light Bucket trap] (AM-K.395587).

Paratypes: 1 male, 1 female, Timor-Leste, Gully $0.5 \mathrm{~km}$ NE of Laclubar, 8.74647S, 125.91497E, $1030 \mathrm{~m}$, Rainforest/garden area fringed with cleared areas, 03 Jun 2012, Timor-Leste Exped., TL2012/107/598 [MV lamp] (AM-K.394714).

Diagnosis. Males of $C$. multidentata are distinguished from the other Timorese species and from all known SE Asian species by the array of sclerotised teeth lining the mesal margin of the inferior appendages. They are somewhat similar to the New Guinea species, C. denticulata Cartwright 2020 from Morobe Province, but C. denticulata has the inferior appendages more slender, especially in the posterior half. The general shape of the female abdomen resembles most closely that of $C$. orumbura Cartwright from northwest Western Australia, but the males of these two species are quite dissimilar.

Description. Body colour: head and thorax yellowish, rest of body brown. Length of each forewing male $3.2-3.6 \mathrm{~mm}(\mathrm{n}=2)$; female $3.3(\mathrm{n}=1)$. Wing venation resembling that of C. lawaliu, but each hind wing with distal margin slightly obliquely, rather than broadly rounded; both wings with forks $1,2,3$, and 5 present, each forewing with small, clear window proximal to discoidal cell, and Rs slightly sinuous basal of discoidal cell. 
Male. Genitalia. Abdominal segment IX deeper than wide, rounded anteroventrally, shallowly concave anterodorsally, ventral process not obvious; anal lobes berry-like in dorsal and lateral views. Segment X stout, membranous, rounded apically, lateral lobes robust, elongate-rectangular in lateral view, narrowly triangular in dorsal and ventral view, with small mesally directed spur subapically. Phallus elongate, when inflated, distal third finely spinulose, spinule lengths ranging from elongate to very short toward apex; two slender dark cornuti internally. Inferior appendages stout, clasper-like, with mesal margins lined with darkly sclerotised 'teeth' (Figs 27-29).

Female. Terminal segments of abdomen forming elongate ovipositor (Fig. 31). Abdominal segment VIII, stout proximally, diameter reduced gradually posteriorly, apicoventral margin with shallow V-shaped excavation. Segment IX elongate, slightly longer than segment VIII and less than half diameter of VIII, apicoventral margin produced posteriorly in pair of lobes. Segment X deeply divided, apical cerci subtended by 4 short stout spines (Fig. 29).

Etymology. Name descriptive of mesal margins of male inferior appendages.

Remarks. Only the holotype has the phallus inflated; similar inflated forms are seen in the specimens of $C$. timorensis and C. lawaliu spp. nov. Presumably, as in heliothine moths, this response is usually triggered during mating (Matthews 1998) and has been seen in other Chimarra species.

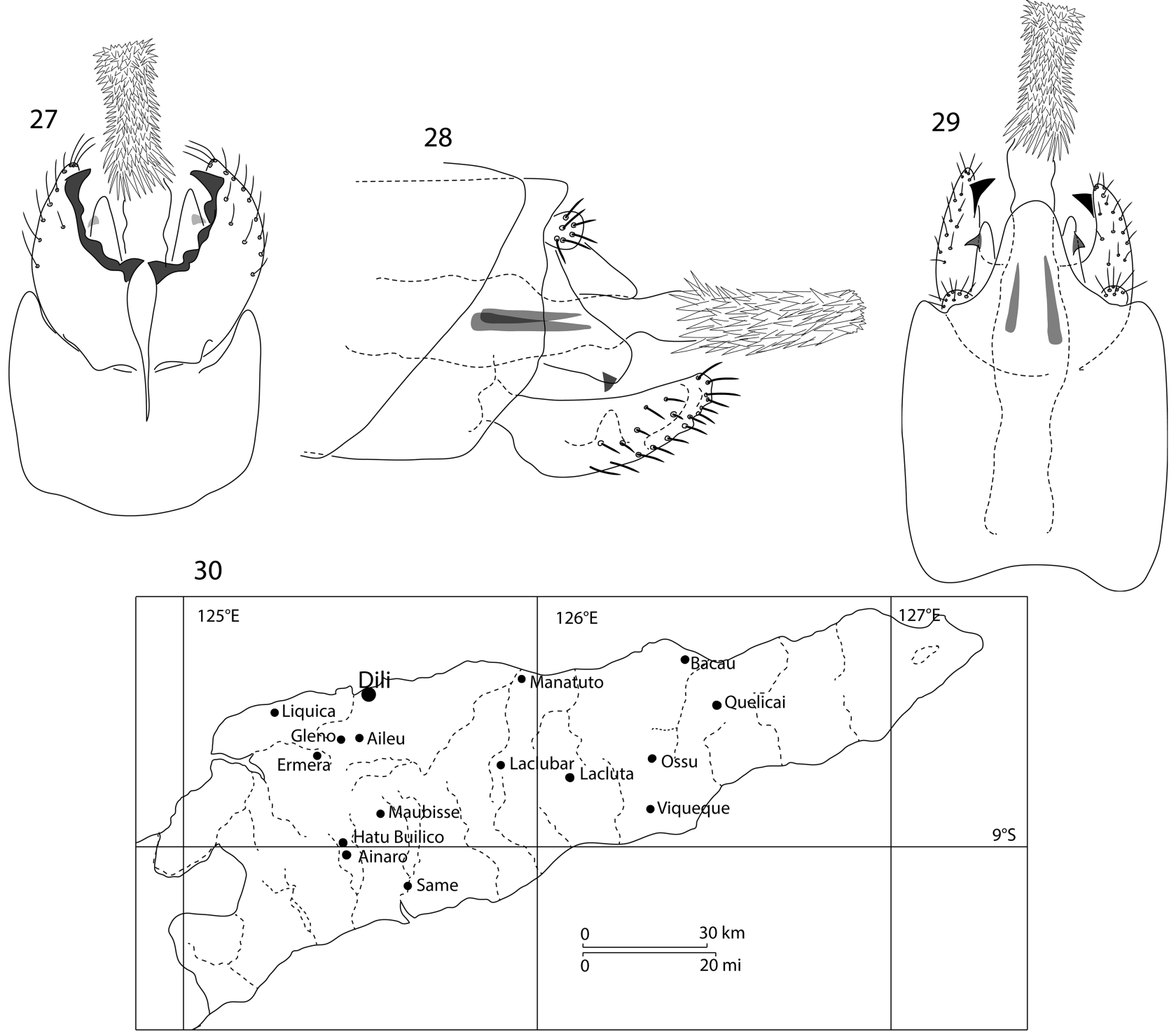

FIGURES 27-30. Chimarra multidentata sp. nov. and map of Timor-Leste. 27-29, C. multidentata, male genitalia: 27, ventral; 28, left lateral; 29, dorsal. 30, map of Timor-Leste, indicating towns closest to some of the collecting sites; water courses indicated by hatched lines. 


\section{HYDROPSYCHIDAE}

Hydropsychids are highly diverse across the SE Asian Region and often abundant. Some 14 genera were illustrated by Malicky (2010) and many of these include large numbers of species. Only one species in each of three genera are reported here from Timor-Leste: Potamyia, Hydropsyche, and the often-species-rich Cheumatopsyche.

Larvae are net spinners, building their nets at the entrance to their fixed tubular retreats, usually on the downstream side of rocks or other substrates.

\section{Cheumatopsyche lucida Ulmer 1907}

Material examined. Timor-Leste: 9 males, 7 females, Loi-Huno 8.77836S, 126.37978E; 29 May 2012, $280 \mathrm{~m}$, Timor-Leste Exp., TL2012/008/044 [Black light/Bucket trap] (AM-K.395557); 10 males, 18 females, Loi-Huno, 8.77836S, 126.37978E, 29 May 2012, 280 m, Timor-Leste Exp. TL2012/008/044 [Black Light / Bucket trap] (AM K.394702); 12 males, 10 females, Quelicai, telecom tower (Mt Lawaliu), 8.58989S, 126.55236E, 03 June 2012, 695 m, Timor-Leste Exp., 2012/017/058 [MV lamp] (AM K.394703); 1 male, Same, Kablaki Hotel, 8.999962S, 125.648072E; 25 May 2012, 490 m, house gardens, Timor-Leste Exp., TL2012/082/540 [house lights] (AM K.394713); 1 male, Beach house nr Baucau, 8.4428S, 126.46906E, 10 m, 05 Jun 2012, beach and foreshore, TimorLeste Exped. TL2012/020/017 [Black light Bucket trap] (AM-K.395593); 5 males, 5 females, Viqueque, Wailakurini via Ossu, 8.799S, 126.3796E, LT In rainforest near river, 10-12 Sept 2016, G. Bellis (ANIC); 5 males, 1 female, Aileu Seloi Malere, Aileu River, UV light, 23.viii.2018, A. Wells \& G. Bellis, 1800-2000 (ANIC).

Remarks. Cheumatopsyche lucida is a widespread SE Asian species with records from Bali, Lombok, Laos, Java, Nicobar Islands, Thailand, and Vietnam (Malicky 2010) and also appears to occur widely across Timor-Leste.

\section{Hydropsyche renschi Mey 1999}

Material examined. Timor-Leste: 1 male, 2 females, Same, Kablaki Hotel, 8.999962S, 125.648072E; 25 May 2012, 490 m, house gardens, Timor-Leste Exp., TL2012/082/540 [house lights] (AM K.395591); 1 male, 8 females, Kablaki Hotel, Same, 8.999969S, 125.648072E, 690 m, 25 May 2012, Timor-Leste exped. TL2012/082/540 [Black light] (AM-K.395580); 3 males, 21 females, Loi-Huno 8.77836S, 126.37978E, 29 May 2012, 280 m, Timor-Leste Exp., TL2012/008/044 [Black light/Bucket trap] (AM-K.395558); 1 male, 1 female, Mount Laritame, Water Tank 2, 8.69081S, 126.38939E, 31 May 2012, 1230 m, edge of moss forest, Timor-Leste Exp., TL2012/012/036 [Black light Bucket trap] (AM K.394711); 2 males, 4 females, Quelicai, telecom tower (Mt Lawaliu), 8.58989S, 126.55236E, 03 June 2012, 695 m, Timor-Leste Exp., 2012/017/058 [MV lamp] (AM-K.395570).

Remarks. Described originally from one male and four females from the island of Lombok and subsequently recorded from Bali and Sumatra (Morse 2021), these records from eastern Timor-Leste extend the known distribution further eastwards in the Indonesian Archipelago.

\section{Potamyia flavata (Banks 1934)}

Material examined. Timor-Leste: 16 males 4 females, Aileu, Seloi Malere, Aileu River, UV light, 23.viii.2018, $\sim 1800-2000 \mathrm{~m}$, A Wells \& G. Bellis (ANIC).

Remarks. This is a widespread species, recorded from Bali, Lombok, Laos, Java, Pen. Malaysia, Thailand, Vietnam, and China.

\section{Polycentropodidae}

One hundred and seventy-five polycentropodid species in seven genera were illustrated by Malicky (2010) for Southeast Asia but only a single species of Polyplectropus was present among collections examined in this study. 
Oláh (2012) listed species in three genera for New Guinea, and Mey and Oláh, in a more recent (but undated) online list gave five genera, including two in Hyalopsychinae; the 3 genera in Polycentropodinae are represented by 30 species. Five genera and 18 species are recorded for Australia (ABRS 2021). Thus, it seems likely that the family is very poorly represented on the island of Timor.

Larval polycentropodids are described as predators of small invertebrates that they trap in funnel-shaped filter nets or actively pursue (Wiggins 2004). They are found in lentic and lotic waters.

\section{Polyplectropus simei Malicky 1993}

Material examined. Timor-Leste: 1 male, Kablaki Hotel, Same, 8.999969S, 125.648072E, 490 m, 26 May 2012, house gardens, D.R. Britton, Timor-Leste exped. TL2012/082/548 [at light] (AM-K.394724); 1 male, Mt Laritame, Water Tank 5, 8.69178S, 126.38719E; 31 May 2012, 1150 m, edge of forest, D. Bickel, A. Mitchell, J. Weiner, V. Kessner \& A. Ribeiro, TL2012/011/016 [Black light/Bucket trap] (AM- K.395574).

Remarks. Until now, Polyplectropus simei was known only from Borneo: it was described from Brunei and subsequently recorded from further north in Sabah (Morse 2021).

\section{Psychomyiidae}

In contrast to Hydropsychidae, Psychomyiidae is not particularly rich in genera in the SE Asian Region, with only seven genera reported. However, several of the genera are rich in species (Paduniella, 26 species; Psychomyia, 61; Tinodes, 58 according to Johanson \& Oláh 2010; Malicky 2010). Three species are recorded here from Timor-Leste, all established species.

Larvae live in 'fixed, meandering silken tubes covered in sand and debris on rocks and other substrates', and reach out to feed on periphyton, extending the tube as close resources become depleted (Wiggins 2004). Fascinating studies by Ings et al. $(2010,2012)$ on a European species of Tinodes found evidence of algal 'gardens' tended by larvae in the more distal parts of the larval silken tube. By tracking isotopes of nitrogen, these authors determined that the gardens are fertilised by the larval faeces, with carbon and nitrogen being recycled through feeding of the larva.

\section{Paduniella koehleri Malicky 1995}

(Fig. 32)

Material examined. Timor-Leste: 3 males, 1 female, Viqueque, Wailakurini via Ossu, 8.799S, 126.3796E, LT, In rainforest near river, 10-12 Sept 2016, G. Bellis (ANIC); numerous males, females, Aileu Seloi Malere, Aileu River, UV light, 23.viii.2018, A. Wells \& G. Bellis (ANIC).

Remarks. Described from Bali and also recorded from Java and Lombok (Morse 2021).

\section{Tinodes nr kawiensis Malicky 1995}

(Figs 33-34)

Material examined. Timor-Leste: 1 male, 2 females, Loi-Huno, 8.77836S, 126.37978E, 29 May 2012, 280 m, Timor-Leste Exp. TL2012/008/044 [Black Light /B. Trap] (AM-K.395565); 1 male, Ainaro District, Guest House, Maubisse, 8.8832S, 125.59636E, 30 May 2012 to 31 May 2012, 1470 m, coffee plantation, D. Britton, TL2012/077/752 [bucket trap, UV light] (AM K.392447); 1 male, Loi-Huno, 8.77836S, 126.37978E, 30 May 2012, 280 m, Timor-Leste Exp. TL2012/008/025 [MV lamp] (AM-K.395564); 1 male, Beach house nr Baucau, 8.4428S, 126.46906E, 10 m, 05 Jun 2012, beach and foreshore, Timor-Leste Exp. TL2012/020/017 [Black light Bucket trap] (AM-K.395594); numerous males, females Viqueque, Wailakurini via Ossu, 8.799S, 126.3796E, LT, in rainforest near river, 10-12 Sept. 2016, G. Bellis (ANIC). 
Remarks. This species identification is somewhat tentative. Tinodes kawiensis was described from a single specimen from Bali and is also recorded from Lombok. The Timorese specimens also show some resemblance to Tinodes kerinciana Oláh \& Johanson 2010 from Sumatra but differ in having a greater array and different arrangement of stout spurs on the inferior appendages.

The larval habitat and the silken tubes the larvae build and live in were described and illustrated by Wells (1995) for one of the two Australian species, Tinodes radona Neboiss 1990.

\section{Lype atnia Malicky \& Chantaramongkol 1993}

(Figs 35-37)

Material examined. 1 male, Timor-Leste, Hatoudo, 8.98189S, 125.62414E; 27 May 2012, 735 m, rainforest, Timor-Leste exped. TL2012/088/561 [gen/sweep] (AM K-395603).

Remarks. This very small species was described from Thailand and reported subsequently from Vietnam and Sumatra. Two other species of Lype are known from the Southeast Asian region: one from Vietnam and another from Taiwan. None has been reported from closer to Timor.

\section{Xiphocentronidae}

Apparently, larvae of Xiphocentronidae are similar in feeding habits to those of Psychomyiidae (Wiggins 2004).

\section{Drepanocentron sp.}

Material examined. 1 male, Timor-Leste, Beach house nr Baucau, 8.4428S, 126.46906E, $10 \mathrm{~m}$, 05 Jun 2012, beach and foreshore, Timor-Leste exped. TL2012/020/017 [Black light Bucket trap] (AM k. 395595).

Remarks. Unfortunately, the single small specimen is inadequate for species description.

\section{Lepidostomatidae}

The genus Lepidostoma appears to be highly speciose in SE Asia: 81 species were illustrated by Malicky (2010), but only six species are recorded from the nearer islands of Indonesia (Malicky et al. 2014).

According to Wiggins (2004) larvae in this family are '...usually found in springs and cool streams, but also occur along shorelines of lakes ... mainly detritivores ...'.

\section{Lepidostoma medium (Banks 1934)}

Material examined. Timor-Leste: $\mathrm{c} 1 \mathrm{~km} \mathrm{NW}$ Same, 8.99702S, 125.64368E, weedy rainforest by river, $460 \mathrm{~m}$, 13-16.xi.2011, C. Reid, site 33 (AM K.324311); 1 female, Ainaro District, Guest House, Maubisse, 8.8832S, 1]25.59636E, 23 May 2012, $1470 \mathrm{~m}$ coffee plantation, Timor-Leste exped. TL2012/077/507 [MV lamp] (AM K.395583); 2 males, 1 female, Kablaki Hotel, Same, 8.999969S, 125.648072E, 690 m, 25 May 2012, Timor-Leste exped. TL2012/082/540 [Black light] (AM-K.395581); 1 male, Loi-Huno, 8.77836S, 126.37978E; 29 May 2012, 280 m, Timor-Leste Exp., TL2012/008/044 [Black light/Bucket trap] (AM-K.395559); 1 female, Ainaro District, Guest House, Maubisse, 8.83372S, 125.59636E, 30 May 2012 to 31 May 2012, 1470 m coffee plantation, D. Britton, TL2012/077/752 [black light bucket trap] (AM K.395596); 2 males, 8 females, Mt Laritame, Water Tank 5, 8.69178S, 126.38719E; 31 May 2012; 1150 m, edge of moss forest, TL2012/011/016 [Black light Bucket trap] (AM K.394712); 1 female, Mount Laritame, Water Tank 2, 8.69081S, 126.38939E, 31 May 2012, 1230 m, edge of moss forest, Timor-Leste exped., TL2012/012/036 [Black light Bucket trap] (AM K.395586); 1 male, 2 females, Quelicai, telecom tower (Mt Lawaliu), 8.58989S, 126.55236E, 03 June 2012, 695 m, Timor-Leste Exp. 2012/017/058 [MV 
lamp] (AM-K.395568); 1 male, gully $0.5 \mathrm{~km} \mathrm{NE}$ of Laclubar, 8.74647S, 125.91497E, $1030 \mathrm{~m}$, Rainforest/garden area fringed with cleared areas, 03 Jun 2012, Timor-Leste Exp., TL2012/107/598 [MV lamp] (AM-K.395592);

Remarks. The males of this species are easily recognised among the Timorese caddisflies by the broadly rounded wings bearing abundant, but sparsely arranged, small dark scales.

The species was described from Sabah in East Malaysia, and until now has not been recorded elsewhere.

\section{Leptoceridae}

The family Leptoceridae is rich in genera in SE Asia, and some of the genera, for example Oecetis, Adicella, and Setodes, are extremely rich in species - with at least 109, 43, and 108 species, respectively (Malicky 2010). Several genera are rich in species in the Australian Region, too. Yet only four leptocerid species are recorded from TimorLeste. The single species of Triplectides recorded here was described from Fiji, and subsequently recorded from the Solomon Islands; this is the second species of Triplectides to be recorded for SE Asia, a marked contrast to the 25 species recorded for Australia (ABRS 2021). The two other leptocerid genera reported here for Timor-Leste are Oecetis and Setodes.

According to reports on behaviour, larval Setodes build sand-grain tube cases and burrow in sand. Merrill \& Wiggins (1971) commented that larvae of Setodes burrow in sandy deposits within depositional areas of fast-moving sandy rivers which could well be adaptive for living in waters that experience sudden spates. Larvae of Oecetis build tube cases of sand, or vegetable material (leaves or sticks) and are generally considered to be predators. In contrast, larval Triplectides live in hollowed out small sticks, reed or sedge or pieces of wood or build messy cases looking like a bundle of thin stems of weed and would be swept away by sudden flood floods; they are opportunist feeders, often gathering detritus.

\section{Triplectides pallidus (Banks 1936)}

Material examined. Timor-Leste: 1 male, Aileu Seloi Malere, Aileu River, sweep net, 21.viii.2018, G. Bellis (ANIC). Larvae of Triplectides species appear to be opportunistic feeders, living in slow waters or lakes and pools. Surprisingly, since specimens of Triplectides species are often quite abundant, only the single specimen was collected (by hand net) and none at the UV lights.

\section{Oecetis peleus Malicky 2005}

Material examined. Timor-Leste: 1 male, Hatoudo, Hato Udo, 8.98189S, 125.62414E, 26 May 2012, 735 m, rainforest, Timor-Leste exped. TL2012/088/546 [MV lamp] (AM-K.394719).

Remarks. Described from Indonesian Borneo (Kalimantan), and until now not recorded elsewhere.

\section{Oecetis keboiwai Salokannel \& Jaakkola 2021 (in Salokannel et al. 2021)}

(Fig. 38)

Material examined. 1 male, Timor-Leste, Loi-Huno, 8.77836S, 126.37978E, 29 May 2012, 280 m, Timor-Leste Exp., TL2012/008/044 [Black light/Bucket trap] (AM-K.394700).

Remarks. Unlike many of the Southeast Asian Oecetis reticulata Group species, a group defined by the unusual feature of abdominal tergite 8 forming a large shield over the genitalia, this Balinese/Timorese species appears to lack darkly sclerotised cornuti in the phallus. In that respect it resembles more closely New Guinean and Australian members of the group. 


\section{Setodes klakahanus Ulmer 1951}

(Fig. 39)

Material examined. Timor Leste: 1 male, Loi-Huno, 8.77836S, 126.37978E, 29 May 2012, 280 m, Timor-Leste Exp., TL2012/008/044 [Black light/Bucket trap] (AM-K.395560); 1 male, Beach house nr Baucau, 8.4428S, 126.46906E, 10 m, 05 Jun 2012, beach and foreshore, Timor-Leste Exp. TL2012/020/017 [Black light/Bucket trap] (AM-K.394715); numerous males, females, Viqueque, Wailakurini via Ossu, 8.799S, 126.3796E, LT, in rainforest near river, 10-12 Sept 2016, G. Bellis (ANIC); 1 male, Daisoli, Aileu, 24 Aug. 2018, swept from citrus, G. Bellis (ANIC); 3 females, Aileu Seloi Malere, Aileu River, UV light, 23.viii.2018, A Wells \& G. Bellis (ANIC).

Remarks. Setodes klakahanus has been recorded from Bali, Java, and Lombok (Morse 2021) and appears to be one of the more widespread species in Timor-Leste.

Merrill \& Wiggins (1971) found that, in the laboratory, Setodes larvae would feed on filamentous algae but also fed voraciously on enchytraeid worms; they suggested that in the field the larvae are probably omnivorous. Bonada et al. (2004) found that a Mediterranean species of Setodes was highly tolerant of sulphates in the water, a factor that could contribute to the broad range of the Setodes species in Timor-Leste.

\section{Checklist of Trichoptera of Timor-Leste}

Hydrobiosidae

Apsilochorema moselyellum Kimmins 1955

Ulmerochorema hatubuilico sp. nov.

Glossosomatidae

Agapetus abbreviatus Ulmer 1913

Hydroptilidae

Hydroptila aileuensis sp. nov.

Hydroptila bellisi $\mathbf{s p .}$ nov.

Oxyethira incana Ulmer 1906

Philopotamidae

Chimarra batukaua Malicky 1995

Chimarra lawaliu sp. nov.

Chimarra multidentata sp. nov.

Chimarra sameana $\mathbf{s p . ~ n o v . ~}$

Chimarra timorensis sp. nov.

Hydropsychidae

Cheumatopsyche lucida (Ulmer 1907)

Hydropsyche renschi Mey 1999

Potamyia flavata (Banks 1934)

Polycentropodidae

Polyplectropus simei Malicky 1993

Psychomyiidae

Paduniella koehleri Malicky 1995

Tinodes nr kawiensis Malicky 1995

Lype atnia Malicky \& Chantaramongkol 1993

Xiphocentronidae

Drepanocentron sp.

Lepidostomatidae

Lepidostoma medium (Banks 1934)

Leptoceridae

Oecetis peleus Malicky 2005

Oecetis keboiwai Salokannel \& Jaakkola 2021 (in Salokannel et al. 2021)

Setodes klakahanus Ulmer 1951

Triplectides pallidus (Banks 1936) 


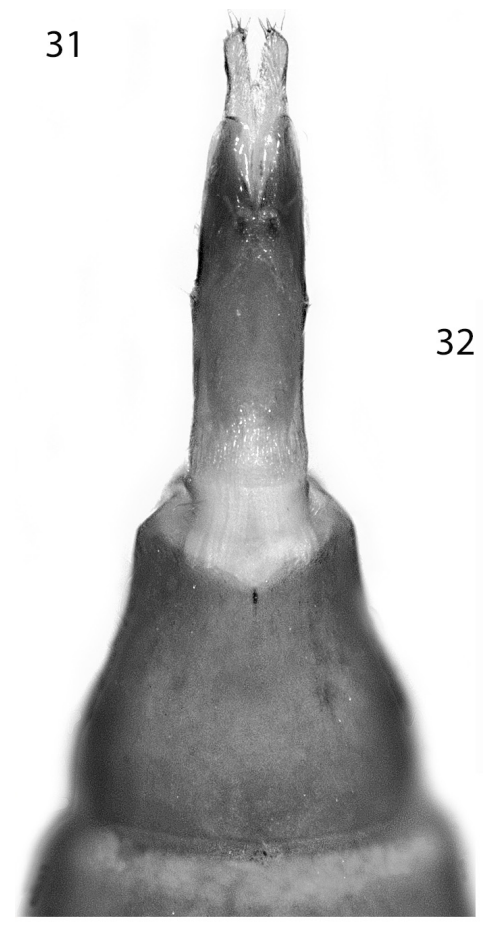

34

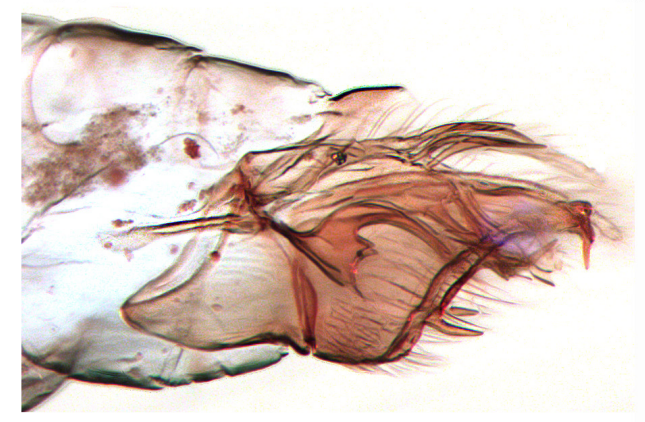

39

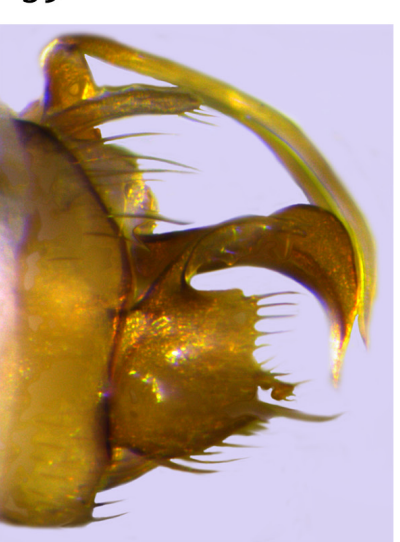

37

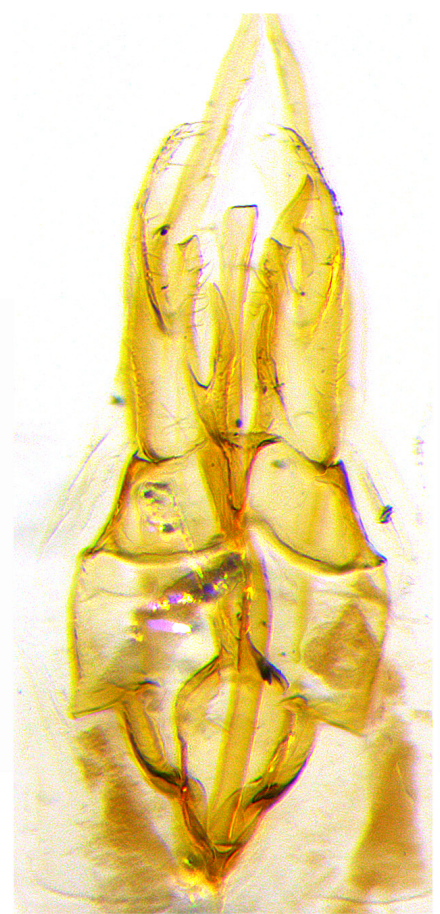

35
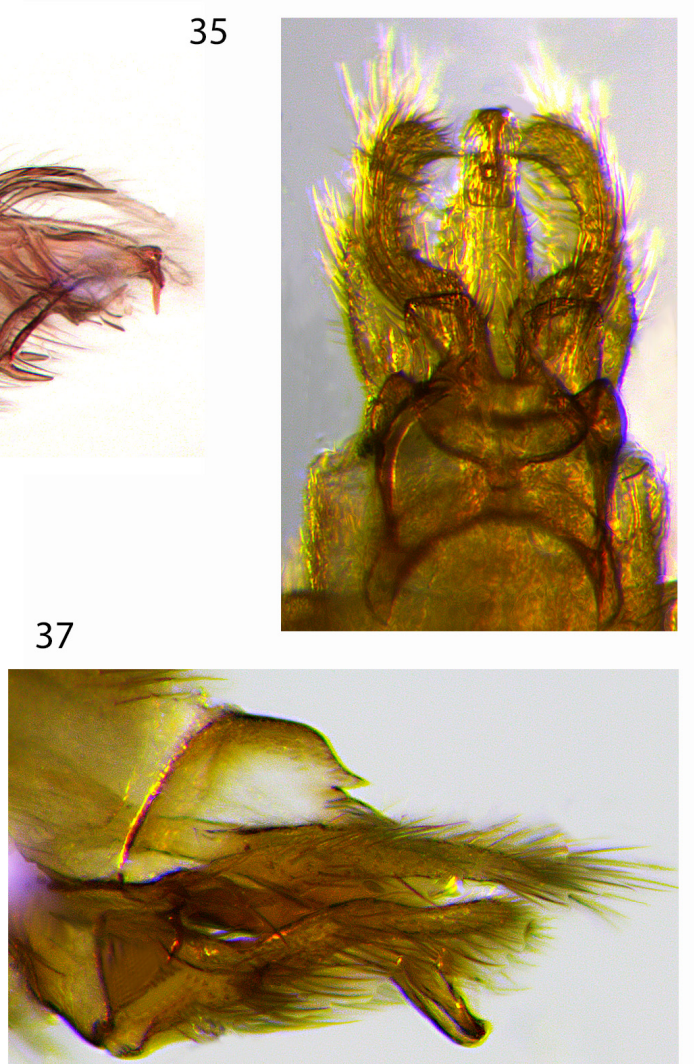

33

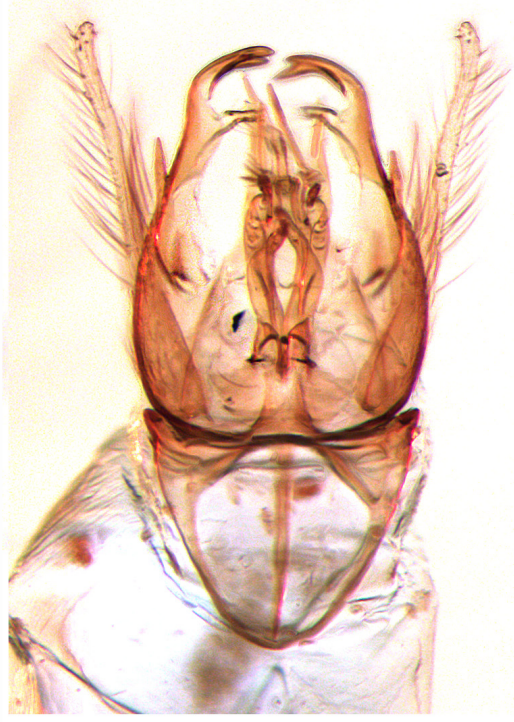

36

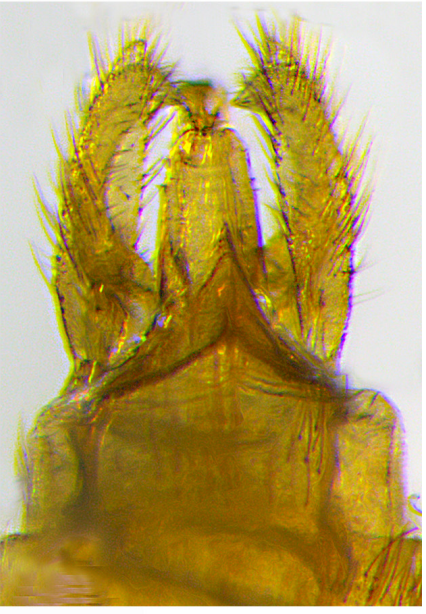

38

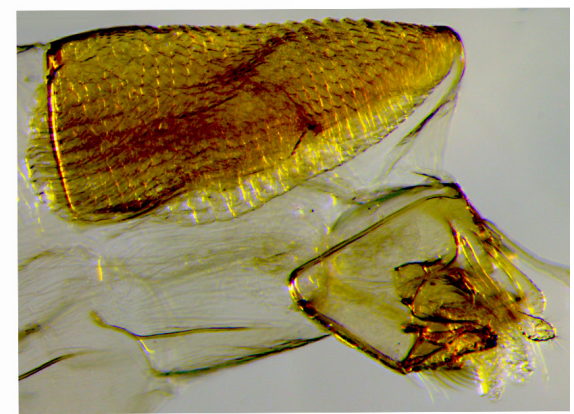

FIGURES 31-39. Trichoptera genitalia. 31, Chimarra multidentata sp. nov., female, ventral. 32, Paduniella koehleri Malicky 1995, male, ventral. 33, 34, Tinodes nr kawiensis Malicky 1995, male genitalia: 33, ventral; 34, left lateral. 35-37, Lype atnia Malicky \& Chantaramongkol 1993: 35, ventral; 36, dorsal; 37, left lateral. 38, Oecetis keboiwai Salokannel \& Jaakkola 2021, male, left lateral. 39, Setodes klakahanus sp. nov., male, left lateral. 


\section{Acknowledgements}

We thank Juha Salokannel and Dr John Morse for their very helpful advice on this paper. The Australian Museum is acknowledged for enabling study of their collection of Timor-Leste Trichoptera, on loan through Derek Smith to Alice Wells. Glenn Bellis donated to ANIC specimens taken in 2016 and 2017 as by-catch of sampling for Culicoides flies and, in 2018, he and Alice Wells collected further specimens during a joint Northern Australian Quarantine Service (NAQS)-Ministry of Agriculture, Forestry and Fisheries (MAFF-Timor-Leste) survey for thrips and other pests in 2018; the supporting organisations and members of the survey team are thanked for facilitating this work.

\section{References}

ABRS (2021) Australian Faunal Directory. Trichoptera. Australian Biological Resources Study, Canberra. Available from: https://biodiversity.org.au/afd/taxa/TRICHOPTERA (accessed 27 July 2021)

Audley-Charles, M.G. (2011) Tectonic post-collision processes in Timor. In: Hall, R., Cottam, M.A. \& Wildon, M.E.J. (Eds.), The SE Asian Gateway: History and Tectonics of the Australia-Asia Collision. Special Publication. Geological Society London, pp. 241-266.

Baehr, M. \& Reid, C.A.M. (2017) On a collection of Carabidae from Timor Leste, with descriptions of nine new species (Insecta: Coleoptera, Carabidae). Records of the Australian Museum, 69 (6), 421-450. https://doi.org/10.3853/j.2201-4349.69.2017.1660

Banks, N. (1934) Supplementary neuropteroid insects from Mr. Kinabalu, Borneo. 38. Journal of the Federated Malay States Museum, 17, 567-578, 23 figs.

Banks, N. (1936) Trichoptera from the Fiji Islands. Psyche, 43, 29-36. https://doi.org/10.1155/1936/18481

Bonada, N., Zamora-Muñoz, C., Rieradevalla, M. \& Prata, N. (2004) Ecological profiles of caddisfly larvae in Mediterranean streams: Implications for bioassessment methods. Environmental Pollution, 132 (2004), 509-521. https://doi.org/10.1016/j.envpol.2004.05.006

Cartwright, D. (2001) Four new species and a new record of Chimarra Stephens (Trichoptera: Philopotamidae) from Bougainville Island, Papua New Guinea. Memoirs of Museum Victoria, 58, 223-230. https://doi.org/10.24199/j.mmv.2001.58.12

Cartwright, D. (2002) The Australian species of Chimarra Stephens (Trichoptera: Philopotamidae). Memoirs of Museum Victoria, 59, 393-437. https://doi.org/10.24199/j.mmv.2002.59.8

Cartwright, D. (2020) A review of the New Guinea species of Chimarra Stephens (Trichoptera: Philopotamidae). Memoirs of Museum Victoria, 79, 1-49. https://doi.org/10.24199/j.mmv.2020.79.01

Ings, N.I., Hildrew, A.G. \& Grey, J. (2012) 'House and garden': Larval galleries enhance resource availability for a sedentary caddisfly. Freshwater Biology, 57 (12), 2526-2538. https://doi.org/10.1111/fwb.12025

Johanson, K.A. \& Oláh, J. (2010) Description of six new species of Oriental Paduniella (Insecta: Trichoptera: Psychomyiidae). Zootaxa, 2548 (1), 43-56. https://doi.org/10.11646/zootaxa.2548.1.3

Kimmins, D.E. (1955) Results of the Oxford University expedition to Sarawak, 1932. Order Trichoptera. Sarawak Museum Journal, 6 (5), 374-442.

Köhler, F. \& Kessner, V. (2014) Mitochondrial and morphological differentiation in a previously unrecognized radiation of the land snail genus Parachloritis Ehrmann, 1912 on Timor (Pulmonata: Camaenidae). Contributions to Zoology, 83 (1), $1-40$. https://doi.org/10.1163/18759866-08301001

Köhler, F., Shea, M. \& Kessner, C. (2019) Two new species of Landouria Godwin-Austen, 1918 from Timor-Leste (Stylommatophora, Camaenidae). Molluscan Research, 39 (3), 253-264. https://doi.org/10.1080/13235818.2018.1557780

Malicky, H. (1993) Neue asiatische Köcherfliegen (Trichoptera: Philopotamidae, Polycentropodidae, Psychomyidae, Ecnomidae, Hydropsychidae, Leptoceridae). Linzer Biologische Beitrage, 25 (2), 1099-1136.

Malicky, H. (1995) Weitere neue Köcherfliegen (Trichoptera) aus Asien. Braueria, 22, 11-26.

Malicky, H. (2005) Beiträge zur Kenntnis asiatischer Oecetis (Trichoptera, Leptoceridae). Linzer Biologische Beiträge, 37 (1), 605-669.

Malicky, H. (2010) Atlas of Southeast Asian Trichoptera. Chiang Mai University, Chiang Mai, 346 pp.

Malicky, H. \& Chantaramongkol, P. (1993) Neue Trichopteren aus Thailand. Teil 1: Rhyacophilidae, Hydrobiosidae, Philopotamidae, Polycentropodidae, Ecnomidae, Psychomyidae, Arctopsychidae, Hydropsychidae. Linzer Biologische Beitrage, 
25 (1), 433-487.

Malicky, H., Melnitsky, S.I. \& Ivanov, V.D. (2014) Caddisflies (Trichoptera) from Lombok, Bali and Java (Indonesia), with a discussion of Wallace's Line. Deutsche Entomologische Zeitschrift, 61 (1), 3-14. https://doi.org/10.3897/dez.61.7046

Marshall, J.E. (1979) A review of the Hydroptilidae (Trichoptera). Bulletin of the British Museum (Natural History) Entomology, 39 (3), 135-239.

Matthews, M. (1998) The CSIRO vesica everter: A new apparatus to inflate and harden eversible and other weakly sclerotised structures in insect genitalia. Journal of Natural History, 32, 317-327. https://doi.org/10.1080/00222939800770161

Merrill, D. \& Wiggins, G.B. (1971) The larva and pupa of the caddisfly genus Setodes in North America (Trichoptera: Leptoceridae). Life Sciences Occasional Papers, Royal Ontario Museum, 19, 1-12. https://doi.org/10.5962/bhl.title.60683

Mey, W. (1999) The Hydropsyche formosana group in the Oriental Region: Taxonomy, distribution and phylogeny (Insecta, Trichoptera: Hydropsychidae). In: Malicky, H. \& Chantaramongkol, P. (Eds.), Proceedings of the $9^{\text {th }}$ International Symposium on Trichoptera, 1999, pp. 227-236.

Mey, W. \& Oláh, J. (2021) The Trichoptera (caddisflies) of Papua Indonesia. Available from: https://www.papua-insects.nl/insect/orders/Trichoptera/ (accessed 27 July 2021).

Morse, J.C. (Ed.) (2021) Trichoptera World Checklist. Available from: http://entweb.clemson.edu/database/trichopt/index.htm (accessed 29 June 2021)

Mosely, M.E. \& Kimmins, D.E. (1953) The Trichoptera (Caddis-flies) of Australia and New Zealand. British Museum (Natural History), London, $550 \mathrm{pp}$. https://doi.org/10.5962/bhl.title.118696

Neboiss, A. (1977) A taxonomic and zoogeographic study of Tasmanian caddis-flies (Insecta: Trichoptera). Memoirs of Museum Victoria, 38, 1-208. https://doi.org/10.24199/j.mmv.1977.38.01

Neboiss, A. (1986) Atlas of Trichoptera of the SW Pacific-Australian Region. Dr W. Junk Publishers, Dordrecht/Boston/Lancaster, $286 \mathrm{pp}$. https://doi.org/10.1007/978-94-009-4814-3

Neboiss, A. (1990) The family Psychomyiidae (Trichoptera) re-established in Australia. Memoires of the Museum of Victoria, $51,83-86$. https://doi.org/10.24199/j.mmv.1990.51.04

Oláh, J. (2012) Taxonomic list of Trichoptera described and recorded from New Guinea region. Folia Historico Naturalia Musei Matraensis, 36, 105-122.

Oláh, J. \& Johanson, K.A. (2010) Fifteen new Trichoptera (Insecta) species from Sumatra, Indonesia. Zootaxa, 2618 (1), $1-$ 35. https://doi.org/10.11646/zootaxa.2618.1.1

Polhemus, D.A. \& Polhemus, J.T. (1994) A new species of Aquarius (Heteroptera: Gerridae) from Timor, with notes on Timorese zoogeography. Proceedings of the Entomological Society of Washington, 96 (1), 54-62.

Salokannel, J., Jaakkola, M., Saaski, A.W. \& Haverinen, R. (2021) Caddisflies from Bali and Lombok with descriptions of two new leptocerids. Braueria, 48, 27-33.

Seehausen, M. (2017) Survey of Odonata from Timor Island, with description of the female of Anax georgius (Odonata: Aeschnidae). Faunistic Studies in South-east Asian and Pacific Island Odonata, 20, 129.

Ulmer, G. (1906) Neuer beitrag zur kenntnis aussereuropäischer Trichopteren. Notes from the Leyden Museum, $28,1-116$.

Ulmer, G. (1907) Neue Trichopteren. Notes from the Leyden Museum, 29, 1-48.

Ulmer, G. (1913) Note IV. Über einige von Jacobson auf Jawa gessamelte Trichopteren. Zweiter Beitrag. Notes from Leyden Museum, 35, 78-101.

Ulmer, G. (1916) Results of Dr. E. Mjöberg's Swedish Scientific expedition to Australia 1910-1913. Trichoptera. Arkiv för Zoologi, 10, 1-23. https://doi.org/10.5962/bhl.part.1501

Ulmer, G. (1951) Kocherfliegen (Trichopteren) von den Sunda-Inseln. Archiv für Hydrobiologie Supplement, 19 , 1-528.

Wells, A. (1995) Larva, pupa and notes on general biology of Tinodes radona Neboiss (Trichoptera: Psychomyiidae. The Beagle, Records of the Museums and Art Galleries of Northern Territory, 12, 53-59. https://doi.org/10.5962/p.264276

Wells, A. \& Huisman, J. (1992) Micro-caddisflies in the tribe Hydroptilini (Trichoptera: Hydroptilidae: Hydroptilinae) from Malaysia and Brunei. Zoologische Mededelingen, Leiden, 66, 91-126.

Wiggins, G.B. (2004) Caddisflies: The Underwater Architects. University of Toronto Press, Toronto, 292 pp. https://doi.org/10.3138/9781442623590 